\title{
PENGARUH KEPRIBADIAN GURU PAI TERHADAP HASIL BELAJAR SISWA DI SEKOLAH
}

\author{
Suardi M \\ Dosen Program Studi Manajemen Informatika \\ Sekolah Tinggi Manajemen Informatika dan Komputer Handayani \\ Jl. Adhyaksa Baru No.1, Kota Makassar, Sulawesi Selatan 90231, Indonesia \\ E-Mail : suardimansing@gmail.com
}

\begin{abstract}
This study aims to determine how the influence of PAI teacher's personality on student learning outcomes in SMA 10 Bulukumba. The approach taken in this study is qualitative research using data collection methods through field research by means of observation and interviews. The data obtained is processed and analyzed through three channels, namely data reduction, data display (presentation) and data verification. The results of the study found that student learning outcomes themselves are influenced by several important factors and it is the responsibility of the teacher to make it happen like motivation, a motivation arises only if because there is a desire to succeed in learning, therefore the personality of a PAI teacher will greatly influence students in learning so that it can improve learning outcomes. Because the personality of a teacher, especially PAI teachers, has a direct and cumulative influence on life and learning habits of students. Students will absorb attitudes, reflect feelings, imitate behavior and cite the teacher's statements. Experience shows that problems related to motivation, discipline, social behavior, achievement and learning desire are derived from the teacher's personality
\end{abstract}

Keywords: Personality;PAI Teacher; Learning Outcomes;

\begin{abstract}
Abstrak
Penelitian ini bertujuan untuk mengetahui bagaimana pengaruh kepribadian guru PAI terhadap hasil belajar siswa di SMA Negeri 10 Bulukumba. Pendekatan yang dilakukan dalam penelitian ini adalah penelitian kualitatif dengan menggunakan metode pengumpulan data melalui penelitian lapangan dengan cara observasi dan wawancara. Data yang diperoleh diolah dan dianalisis melalui tiga alur, yakni reduksi data, display data (penyajian) dan verifikasi data. Hasil penelitian ditemukan bahwa hasil belajar siswa sendiri di pengaruhi oleh beberapa faktor penting dan menjadi tanggung jawab guru untuk mewujudkannya seperti motivasi, sebuah motivasi timbul hanya jika karena ada keinginan untuk berhasil dalam belajar, olehnya karena itu kepribadian seorang guru PAI akan sangat mempengaruhi siswa dalam pembelajaran sehingga dapat meningkatkan hasil belajarnya. Sebab kepribadian seorang guru khususnya guru PAI mempunyai pengaruh langsung dan kumulatif terhadap hidup dan kebiasaan- kebiasaan belajar peserta didik. Peserta didik akan menyerap sikap-sikap, merefleksikan perasaan-perasaan, meniru tingkah laku dan mengutip pernyataan-pernyataan gurunya. Pengalaman menunjukkan bahwa masalah-masalah yang berkaitan dengan motivasi, disiplin, tingkah laku sosial, prestasi dan hasrat belajar bersumber dari kepribadian guru
\end{abstract}

Kata Kunci: Kepribadian; Guru PAI; Hasil Belajar; 


\section{PENDAHULUAN}

Dunia pendidikan dewasa ini berkembang semakin pesat membuat persoalan pendidikan semakin kompleks sehingga memerlukan pemikiran yang konstruktif demi tercapainya kualitas pendidikan yang baik secara umum. Salah satu persoalan yang dimaksud adalah kompetensi mengajar guru sebab gurulah sebagai orang yang berwenang dan bertanggung jawab terhadap pendidikan siswa, baik secara individual maupun secara klasikal, baik itu di sekolah maupun diluar sekolah minimal harus memiliki dasar-dasar kompetensi sebagai wewenang dalam menjalankan tugasnya. ${ }^{1}$

Pada dasarnya kompetensi menunjukan pada kecakapan atau kemampuan untuk mengerjakan sesuatu pekerjaan. Sedangkan definisi kedua menunjukkan lebih lanjut bahwa kompetensi itu pada dasarnya merupakan suatu sifat (karakteristik) orang-orang (kompeten) yang memiliki kecakapan, daya (kemampuan) otoritas (kewenangan), kemahiran (keterampilan), pengetahuan, dan sebagainya untuk mengerjakan apa yang diperlukan. Sedangkan definisi ketiga lebih jauh lagi bahwa kompetensi itu menunjukkan kepada tindakan (kinerja) rasional yang dapat mencapai tujuan-tujuannya secara memuaskan berdasarkan kondisi (prasyarat) yang diharapkan. ${ }^{2}$

Sehingga seorang guru perlu memiliki kepribadian, menguasai bahan pelajaran dan menguasai cara-cara mengajar sebagai kompetensinya. Tanpa hal tersebut guru akan gagal dalam melaksanakan tugasnya. Jadi kompetensi mengajar harus dimilki oleh seorang guru yang merupakan keterampilan dalam mengelolah kegiatan pendidikan. Dengan demikian guru yang mempunyai kompetensi mengajar mampu menciptakan lingkungan belajar yang efektif dan menyenangkan serta lebih mampu mengelolah kelasnya sehingga hasil belajar siswa berada pada tingkat optimal. Disamping hal tersebut diatas, kompetensi dalam proses interaksi belajar mengajar dapat pula menjadi alat motivasi ekstrinsik, guna memberikan dorongan dari luar diri siswa. 1991).

${ }^{1}$ Saiful Bahri Djamarah, Prestasi Belajar Dan Kompetensi Mengajar (Surabaya: Usaha Nasional,

2 Nana Syahodih and Sukamdinata, Landasa Psikologi Proses Pendidikan (Bandung: Remaja Rosda Karya, 2003). 
Kepribadian tersebut sangat penting artinya bagi seorang guru agar berhasil dalam pengajarannya sebab dengan kepribadian akan mempengaruhi anak dalam proses belajar mengajar sebagaimana dikatakan bahwa kepribadian guru lebih besar pengaruhnya dari pada kepandaian dan ilmunya, terutama anak didik yang dalam usia kanak-kanak dan masa meningkat remaja, yaitu tingkat pendidikan dasar dan menengah karena anak didik pada tingkat tersebut masih dalam masa pertumbuhan. Dan selanjutnya dikatakan bahwa perasaan dan emosi guru yang mempunyai kepribadian terpadu tampak stabil, optimis dan menyenangkan, dia dapat memikat hati anak didiknya, karena setiap anak merasa diterima dan di sayangi oleh guru, betapapun sikap dan tingkah lakunya. ${ }^{3}$

Agar para guru agama dapat menjalankan tugasnya dengan baik maka dibutuhkan adanya syarat-syarat tertentu disamping syarat-syarat yang harus dimiliki oleh guru pada umumnya, adapun syarat tersebut adalah sebuah kepribadian. Kepribadian yang merupakan persyaratan dari seorang guru meliputi sikap, minat, kelakuan dan tabi'at (moral). Olehnya karena itu menjadi sangat penting untuk mengetahui seperti apa dan bahkan sejauh mana pengaruh kepribadian guru terhadap hasil belajar siswa secara umum yang merupakan akumulasi dari pengetahuan akademik dan sikap serta mental siswa disekolah.

\section{KERANGKA TEORI}

\section{Kepribadian Guru}

Syaiful Bahri Djamarah menjelaskan bahwa figur guru yang mulia ialah sosok guru yang dengan rela hati menyisihkan waktunya demi kepentingan anak didik, demi membimbing, mendengarkan keluhan, menasehati, membantu kesulitan mereka dalam segala hal yang bisa menghargai aktivitas belajarnya, merasakan kedukaan bersama-sama dengan mereka pada waktu senggang, berbicara dan bersenda gurau di sekolah maupun di luar jam pelajaran. ${ }^{4}$ Lebih lanjut Syaiful Bahri menegaskan bahwa Guru adalah spiritual father atau bapak rohani seorang anak didik. Guru diharapkan senantiasa memberikan santapan jiwa dengan ilmu, pendidikan akhlak maupun keagamaan. Maka menghormati guru berarti menghormati anak didik, menghargai guru berarti memberikan penghargaan terhadap mereka karena dengan peran guru, mereka berkembang dan guru dapat

\footnotetext{
${ }^{3}$ Zakiah Daradjat, Kepribadian Guru (Jakarta: Bulan Bintang, 2005).

${ }^{4}$ Saiful Bahri Djamarah, Guru Dan Anak Didik Dalam Interaksi Edukatif (Jakarta: Rineka Ciptas, 2005).
} 
melaksanakan tugas dengan sebaik-baiknya sebagai seorang pribadi yang terpanggil.

Kompetensi Kepribadian Guru PAI

Kepribadian sebenarnya adalah suatu masalah yang abstrak, hanya dapat dilihat lewat penampilan, tindakan, ucapan, cara berpakaian, dan dalam menghadapi setiap persoalan. Kepribadian yang sesungguhnya adalah abstrak (ma'nawi), sukar dilihat atau diketahui secara nyata, yang dapat diketahui adalah penampilan atau bekasnya dalam segala segi dan aspek kehidupan. Misalnya dalam tindakannya, ucapan, cara bergaul, berpakaian, dan dalam menghadapi setiap persoalan atau masalah, baik yang ringan maupun yang berat.

Guru sebagai profesi atau jabatan atau pekerjaan yang memerlukan keahlian khusus sehingga pekerjaan ini tidak dapat dilakukan oleh sembarang orang di luar bidang kependidikan, walaupun kenyataannya masih dilakukan. Itulah sebabnya jenis profesi ni mudah terkena pencemaran. Dalam konsep pendidikan tradisional Islam, posisi guru begitu terhormat. Guru diposisikan sebagai seorang yang alim, wara', shalih, dan sebagai uswah sehingga guru dituntut juga beramal saleh sebagai aktualisasi dari keilmuan yang dimilikinya. Oleh karena itu, wajar jika mereka diposisikan sebagai orang-orang penting dan mempunyai pengaruh besar pada masanya dan seolah-olah memegang kunci keselamatan rohani dalam masyarakat. ${ }^{5}$

\section{Hasil Belajar}

Lembaga pendidikan formal menggunakan suatu acuan penilaian tertentu untuk mengukur hasil belajar. Oemar Hamalik menjelaskan hasil belajar adalah sesuatu yang diperoleh dari proses belajar. ${ }^{6}$ Hasil belajar tersebut diwujudkan dengan nilai atau angka tertentu yang mencerminkan suatu hasil, akibatnya adalah adanya perubahan kognitif, afektif, maupun psikomotorik. Sedangkan hasil belajar menurut Nana Sudjana adalah kemampuan yang dimiliki siswa setelah menerima pengalaman belajar. Hasil belajar merupakan perilaku berupa pengetahuan, keterampilan, sikap, informasi, strategi kognitif yang baru dan diperoleh siswa setelah berinteraksi dengan lingkungan dalam suatu suasana atau kondisi pembelajaran. ${ }^{7}$

Hasil belajar seringkali digunakan sebagai ukuran untuk mengetahui seberapa jauh seseorang menguasai bahan yang sudah diajarkan. Untuk mengaktualisasikan hasil belajar tersebut diperlukan serangkaian pengukuran menggunakan alat evaluasi yang baik dan memenuhi syarat. Pengukuran demikian dimungkinkan karena pengukuran merupakan kegiatan ilmiah yang dapat diterapkan pada berbagai bidang termasuk pendidikan.

\footnotetext{
${ }^{5}$ Ngainum Naim, Menjadi Guru Inspiratif (Jogjakarta: Pustaka pelajar, 2009).

${ }^{6}$ Oemar Hamalik, Teknik Pengukuran Dan Evaluasi Pendidikan (Bandung: Mandar Maju, 2005).

${ }^{7}$ Nana Sudjana, Penilaian Hasil Proses Belajar Mengajar (Bnadung: Remaja Rosdakarya, 2009).
} 
Menurut M. Ngalim Purwanto bahwa pengukuran hasil belajar siswa dapat dilakukan dengan tes hasil belajar, yang dimaksud tes hasil belajar adalah tes yang dipergunakan untuk menilai hasil-hasil pelajaran yang telah diberikan oleh guru kepada murid-muridnya dalam jangka waktu tertentu. Dalam hal ini pemberian tes hasil belajar harus disesuaikan dengan tipe hasil belajar mana yang akan dinilai. ${ }^{8}$

\section{Pengaruh Kepribadian Guru Terhadap Siswa}

Pengaruh adalah daya yang ada atau timbul dari sesuatu (orang, benda) yang ikut membentuk watak, kepercayaan, atau perbuatan seseorang. Kepribadian seorang guru adalah faktor yang sangat berpengaruh terhadap keberhasilan seorang guru sebagai pengembang sumber daya manusia. Oleh karena itu, setiap guru professional sangat diharapkan untuk memahami kepribadian (personality) dirinya yang diperlukan sebagai panutan para siswa. Terkait dengan kepribadian, guru diharapkan mampu mengenali ciri khas kepribadian seperti yang dikemukakan oleh Muhibbin Syah bahwa keberhasilan guru dalam menggeluti profesinya meliputi fleksibilitas kognitif dan keterbukaan psikologis. Fleksibilitas kognitif yang dimaksudkan ialah kemampuan berpikir yang diikuti dengan tindakan yang memadai dalam situasi tertentu. ${ }^{9}$

Karakter kepribadian seorang guru akan sangat mempengaruhi siswa dalam pembelajaran. Suyanto dan Asep Jihad menegaskan bahwa kepribadian seorang guru mempunyai pengaruh secara langsung dan kumulatif terhadap hidup dan kebiasaan- kebiasaan belajar peserta didik. Peserta didik akan menyerap sikapsikap, merefleksikan perasaan-perasaan, menyerap keyakinan-keyakinan, meniru tingkah laku dan mengutip pernyataan-pernyatan gurunya. ${ }^{10}$ Pengalamanpengalaman menunjukkan bahwa masalah-masalah yang berkaitan dengan motivasi, disiplin, tingkah laku sosial, prestasi dan hasrat belajar bersumber dari kepribadian guru.

Guru yang ramah dan penyayang akan menciptakan iklim yang kondusif dan memberikan aura positif terhadap perkembangan psikis peseta didik. Peserta didik akan merasa aman, nyaman dan senang belajar di kelas. Peserta didik juga akan termotivasi untuk belajar dan mau menaati peraturan yang dikeluarkan oleh guru. Sebaliknya, guru yang keras dan pemarah akan menimbulkan iklim kelas yang mencekam. Kelas yang mencekam dan tidak menyenangkan dapat menimbulkan dampak negatif bagi peserta didik. Biasanya melakukan protes dalam bentuk kenakalan seperti membuat gaduh, tidak memperhatikan pelajaran dan lain-lain. Kondisi kelas yang seperti ini tentu akan menurunkan prestasi belajar siswa.

\footnotetext{
${ }^{8}$ M Ngalim Purwanto, Prinsip-Prinsip Dan Teknik Evaluasi Pengajaran (Bandung: Remaja Rosdakarya, 2012).

${ }^{9}$ Muhibbin Syah, Psikologi Pendidikan (Bandung: Remaja Rosda Karya, 2014).

${ }^{10}$ Suyanto and Asep Jihad, Menjadi Guru Professional: Strategi Meningkatkan Kualifikasi Dan Kualitas Guru Di Era Global (Jakarta: Erlangga, 2013).
} 


\section{METODE PENELITIAN}

Penelitian ini adalah penelitian kualitatif yang bersifat deskriptif yakni penelitian yang berusaha menyajikan data, menganalisis dan menginterpretasi untuk menuturkan pemecahan masalah yang ada sekarang berdasarkan data.

Sumber data yang digunakan yakni data primer, seperti wawancara, hasil observasi, dan dokumen tertulis yang ada pada objek penelitian dan data sekunder, seperti sumber buku, majalah, arsip, ataupun dokumen resmi yang terkait dalam pembahasan penelitian ini. Tehnik pengolahan dan analisis data yaitu dengan melakukan library research dan field research setelah itu reduksi data, penyajian data, lalu verifikasi yaitu penarikan suatu kesimpulan.

\section{PENGARUH KEPRIBADIAN GURU PAI TERHADAP HASIL BELAJAR SISWA DI SMA NEGERI 10 BULUKUMBA}

Dalam konsep pendidikan tradisional Islam, posisi guru begitu terhormat. Guru diposisikan sebagai seorang yang „alim, wara", shalih, dan sebagai uswah sehingga guru dituntut juga beramal saleh sebagai aktualisasi dari keilmuan yang dimilikinya. Oleh karena itu, wajar jika mereka diposisikan sebagai orang-orang penting dan mempunyai pengaruh dalam masyarakat. Berdasarkan hasil penelitian yang di lakukan di SMA Negeri 10 Bulukumba di ketahui dari hasil wawancara dengan guru PAI kelas X, Yuhana bahwa :

"Guru PAI harus berbeda dengan guru-guru yang lain sebab dalam pelajaran agama kita dituntut dua hal secara garis besar, yang pertama pengetahuan siswa dan yang kedua tentunya akhlak siswa dan itu harus seimbang 50:50. Bagaimana kita "guru" menuntut siswa untuk memperbaiki akhlaknya jika kita sendiri sebagai guru agamanya tidak terlebih dahulu menjadi teladan dengan memperlihatkan kepribadian yang baik yang sejalan dengan nilai-nilai keagamaan".

Tugas guru sebagai pendidik juga berarti meneruskan dan mengembangkan nilai-nilai hidup dan tugasnya sebagai pengajar berarti meneruskan dan mengembangkan ilmu pengetahuan dan teknologi. Para siswa akan enggan menghadapi guru yang tidak menarik perhatian mereka. Alhasil, pelajaran tidak dapat diserap para siswa sehingga setiap lapisan ilmu tidak bisa dikaji lebih mendalam. Para siswa menjadi apatis dengan apa yang disampaikan oleh guru. Tidak mengherankan jika banyak siswa yang melampiaskan keengganan dan keapatisan tersebut pada hal-hal dan aktivitas yang tidak baik. Seperti yang disampaikan lebih lanjut oleh Yuhana yang menjelaskan bahwa :

"Seorang guru agama, saya kira memang perlu mencerminkan kepribadian yang jauh lebih menarik dimata siswa yang sesuai dengan norma-norma yang berlaku bahkan kenapa tidak dengan guru mata pelajaran yang lain sebab 
kepribadian guru saya kira juga sangat menetukan kenyamanan siswa dalam belajar, meski siswa berada yang ruang kelas yang mewah namun kepribadian gurunya misalnya galak maka saya yakin ruang belajar itupun akan terasa gerah dan sesak bagi siswa dan sebaliknya meski ruang belajarnya sederhana tapi jika sikap dan kepribadian gurunya baik, ramah, sejuk dan bersahabat dengan siswa maka siswa pasti akan sangat happy dalam belajar dan pasti akan sangat berpengaruh terhadap hasil belajarnya".

Dari wawancara diatas dapat ditarik kesimpulan bahwa kepribadian guru PAI merupakan cermin, baik atau tidaknya akhlak seorang siswa dan dilain sisi, kepribadian guru PAI ataupun guru pada umumnya yang baik, bersahabat, sejuk dan ramah dalam proses interaksi dengan siswa, baik dalam kelas maupun secara umum dalam lingkungan sekolah dapat meningkatkan antusisme dan kesenangan siswa dalam belajar yang dapat berimplikasi pada penentuan hasil belajar siswa.

Hasil belajar yang dicapai peserta didik dipengaruhi oleh dua faktor utama yakni faktor intrinsik dan faktor ekstrinsik. Faktor intrinsik terutama kemampuan yang dimilikinya. Faktor kemampuan besar sekali pengaruhnya terhadap prestasi belajar yang dicapai. Disamping faktor kemampuan yang dimiliki peserta didik, juga ada faktor lain, seperti motivasi belajar, minat dan perhatian, sikap dan kebiasaan belajar, ketekunan, faktor fisik dan psikis, sebagaimana pada wawancara lain, yaitu dengan Rosnaeni yang juga guru PAI untuk kelas XI pada SMA Negeri 10 Bulukumba, menjelaskan bahwa :

"Hasil belajar anak yang baik atau berprestasi atau tidaknya ditentukan sejauh mana dia disiplin atau tekun dalam belajar baik pengetahuannya, sikap dan keterampilannya sehingga guru sebenarnya sangat penting mengarahkan siswa agar dapat disiplin, yaa tergantung cara kita apakah dengan sedikit memaksanya atau tidak bosan-bosannya kita dalam membujuk sang anak agar tetap disiplin dalam belajar dikelas dan dilingkungan sekolah secara umum dengan harapan dilingkungan keluarganya juga dapat didik demikian disiplinnya dan membujuk itu bisa dengan kata-kata ajakan dan juga dengan sikap teladan, mencontohkan".

Ada faktor-faktor yang berada di luar diri siswa yang dapat menentukan atau mempengaruhi hasil belajar yang dicapai. Hasil belajar yang dapat diraih senantiasa bergantung dari lingkungan belajarnya dikelas seperti guru dan suasana belajar dan itu tentukan oleh guru melalui kepemiminannya dikelas yang diimplementasikan melalui sikap dan kepribadiannya. Seperti yang disampaikan oleh Kamus Mustamin sebagai guru PAI untuk kelas XII di SMA Negeri 10 Bulukumba, bahwa :

"Saya kira ada pengaruhnya antara kepribadian guru, khususnya guru PAI terhadap peningkatan hasil belajar siswa baik itu pada mata pelajaran PAI sendiri maupun dengan mata pelajaran yang lain. Saya dapat melihat peningkatan itu dengan sikap antusias siswa saat dikelas jika saya kadang terpancing marah atau cuek dibandingkan saat saya bersikap bersahabat 
dengan mereka, para siswa dan kita semua pasti setuju dan sepakat bahwa jika siswa memiliki motivasi atau antusias yang tinggi terhadap proses belajar maka itu akan mengangkat prestasi hasil belajarnya".

\section{PENUTUP}

Dari hasil penelitian yang telah dilakukan dan dijelaskan dalam pembahasan, maka ditarik kesimpulan bahwa hasil belajar siswa sendiri di pengaruhi oleh beberapa faktor penting dan menjadi tanggung jawab guru untuk mewujudkannya seperti motivasi, sebuah motivasi timbul hanya jika karena ada keinginan untuk berhasil dalam belajar, olehnya karena itu kepribadian seorang guru PAI akan sangat mempengaruhi siswa dalam pembelajaran sehingga dapat meningkatkan hasil belajarnya disekolah. Sebab kepribadian seorang guru khususnya guru PAI mempunyai pengaruh langsung dan kumulatif terhadap hidup dan kebiasaankebiasaan belajar siswa. Siswa akan menyerap sikap-sikap, merefleksikan perasaan-perasaan, meniru tingkah laku dan mengutip pernyataan-pernyataan gurunya. Pengalaman menunjukkan bahwa masalah-masalah yang berkaitan dengan motivasi, disiplin, tingkah laku sosial, prestasi dan hasrat belajar bersumber dari kepribadian guru.

\section{DAFTAR PUSTAKA}

Daradjat, Zakiah. Kepribadian Guru. Jakarta: Bulan Bintang, 2005.

Djamarah, Saiful Bahri. Guru Dan Anak Didik Dalam Interaksi Edukatif. Jakarta: Rineka Ciptas, 2005.

_-_- Prestasi Belajar Dan Kompetensi Mengajar. Surabaya: Usaha Nasional, 1991. Hamalik, Oemar. Teknik Pengukuran Dan Evaluasi Pendidikan. Bandung: Mandar Maju, 2005.

Naim, Ngainum. Menjadi Guru Inspiratif. Jogjakarta: Pustaka pelajar, 2009.

Purwanto, M Ngalim. Prinsip-Prinsip Dan Teknik Evaluasi Pengajaran. Bandung: Remaja Rosdakarya, 2012.

Sudjana, Nana. Penilaian Hasil Proses Belajar Mengajar. Bnadung: Remaja Rosdakarya, 2009.

Suyanto, and Asep Jihad. Menjadi Guru Professional: Strategi Meningkatkan Kualifikasi Dan Kualitas Guru Di Era Global. Jakarta: Erlangga, 2013.

Syah, Muhibbin. Psikologi Pendidikan. Bandung: Remaja Rosda Karya, 2014.

Syahodih, Nana, and Sukamdinata. Landasa Psikologi Proses Pendidikan. Bandung: Remaja Rosda Karya, 2003. 